\title{
스테로이드로 치료한 후천특발전신무한증 환자의 예후
}

\author{
조은빈 ${ }^{1,2,3}$, 김승주 ${ }^{1}$, 양태원 $^{1}$, 정희정 ${ }^{1}$, 윤창효 $^{1}$, 정승욱 ${ }^{1,2,3}$, 박기종 ${ }^{1,2,3}$ \\ 1창원경상대학교병원 신경과, ${ }^{2}$ 경상대학교 의과대학 신경과학교실, ${ }^{3}$ 경상대학교 건강과학연구원
}

\section{Prognosis of Patients with Acquired Idiopathic Generalized Anhidrosis Treated with Steroids}

\author{
Eun Bin Cho ${ }^{1,2,3}$, Seung Joo Kim¹, Tae-Won Yang ${ }^{1}$, Heejeong Jeong ${ }^{1}$, Chang Hyo Yoon ${ }^{1}$, Seunguk Jung ${ }^{1,2,3}$, Ki-Jong Park ${ }^{1,2,3}$ \\ ${ }^{1}$ Department of Neurology, Gyeongsang National University Changwon Hospital, Changwon, ${ }^{2}$ Department of Neurology, Gyeongsang National \\ University, College of Medicine, ${ }^{3}$ Gyeongsang Institute of Health Science, Gyeongsang National University, Jinju, Korea
}

Objective: To elucidate the response to steroid therapy and prognosis in patients with acquired idiopathic generalized anhidrosis (AIGA).

Method: We reviewed the medical records of patients seen at a tertiary neurology clinic between March 2017 and July 2019. Inclusion criteria required the diagnosis of widely distributed anhidrosis, affecting at least $50 \%$ of the entire body, in the absence of any other autonomic or neurologic dysfunction. The diagnosis and distribution of generalized anhidrosis were confirmed using thermoregulatory sweat test.

Results: Six male patients were included with a mean age at onset of 32 years (range, 16 43 years). All patients received corticosteroid therapy with five consecutive days of intravenous $1 \mathrm{~g}$ methylprednisolone and oral prednisolone. Five patients showed good response to steroid therapy. However, decreased sweating reappeared in more than a half of patients $(N=3 / 5)$ with a mean interval of 32 days (standard deviation, 7.5) until recurrence. The differentiated findings in patients with recurrence compared to those without were anhidrosis over a wider part of body on quantitative sudomotor axon reflex test and decreased heart rate variability to deep breathing.

Conclusion: Corticosteroid therapy was effective in improving AIGA symptoms. However, recurrence rates seem to be high after treatment discontinuation and prognostic factors need to be confirmed.

Key Words: anhidrosis, treatment, prognosis

Received October 21, 2019

Revised November 20, 2019

Accepted November 30, 2019

Corresponding Author: Ki-Jong Park

Department of Neurology, Gyeongsang National University College of Medicine,

11 Samjeongja-ro, Seongsan-gu, Changwon 51472, Korea

Tel: 82-55-214-2639, Fax: 82-55-214-2638, E-mail: pkjong@gnu.ac.kr
서 론

후천특발전신무한증(acquired idiopathic generalized anhidrosis)은 땀을 분비하지 못하는 드문 질환으로, 이를 진단하기 위해서는 증상을 유발할 수 있는 뚜렷한 피부질 환이나 대사 및 내분비 장애, 신경계질환이 동반되지 않아 야 한다. ${ }^{1}$ 대체적으로 땀분비 감소 혹은 땀이 나지 않는 부 위가 전체 표면적의 $25 \%$ 이상을 차지할 경우로 정의되기 
도 한다. ${ }^{2}$ 현재까지 이 질환의 유병률 및 발병률에 대한 역 학 보고는 없으며, 대부분의 증례가 일본에서 보고되어 인 종 및 지역적 차이가 있을 수 있음을 시사하였으나 아직 명 확하지 않다. 고용량 스테로이드가 초기 치료로 추천되나, 적절한 용량 및 치료 기간에 대하여는 아직 공통된 의견이 없다. 이 질환의 자연경과 및 예후에 대해 아는 것이 치료 에 중요하겠으나, 현재까지 이러한 자료는 없는 실정이다. 본 연구의 목적은 후천특발전신무한증 환자들의 스테로이 드에 대한 반응성 및 예후를 살펴보고자 함이다.

\section{연구대상 및 방법}

2017년 3월부터 2019년 7월 사이에 본원 신경과를 내 원한 환자들의 기록을 살펴보았다. 이들 중, 신체의 $50 \%$ 이 상에서 땀이 나지 않는 것을 온도조절 발한 검사(thermoregulatory sweat test)로 확인한 자들을 연구대상으로 선 정하였다. 무한증이 당뇨병, 쇼그렌 증후군, 파브리병과 같은 질환으로인해 이차적으로 발생하거나, 항콜린계 약 물 등 무한증 유발 가능 약물을 복용한 경우는 제외하였 다. 온도조절 발한 검사는 인공기상방(artificial climate room; 온도 40도)에서 시행하였다. 모든 환자에서 약물 복 용력을 파악하고 기본 피검사를 시행하였으며, 특히 쇼그 렌증후군을 배제하기 위하여 항핵항체(fluorescent antinuclear antibody; FANA), 항 SSA/SSB (anti-Sjögren'ssyndrome-related antigen A/anti-Sjögren's-syndromerelated antigen B) 항체, 눈물분비량검사(Shirmer test) 등 을 시행하였다. 의무기록을 통해 역학 및 임상자료를 모았 으며, 나이, 성별, 체질량지수, 증상 발생 나이, 유병기간, 치
료방법, 자율신경검사(심호흡시 심박동변이, 발살바 수기, 기립경사테이블검사, 정량적발한축삭반사검사) 결과 및 피 부조직검사 결과를 포함하였다.

\section{결 과}

연구 대상자는 여섯 명이었으며, 증상발생 평균연령은 32세(범위, 16 43세)인 젊은 남자들이었다(Table 1). 병 원 내원 시 평균 이환기간은 152일(범위, 22 564일)이며, 병원 진료기간은 평균 7.9 개월(범위, 3.5 14.2개월)이었 다. 모든 환자들은 내원 시 땀이 나지 않는다는 것을 인지 하고 있었으며, 4 명(67\%)은 콜린성 두드러기를 호소하였 다. 온도조절 발한 검사에서 겨드랑이, 손바닥, 발바닥을 제외한 대부분의 신체에서 땀이 나지 않음을 확인할 수 있 었다. 한쪽 아래팔, 근위부 하지, 원위부 하지, 발에서 시 행한 정량적발한축삭반사검사에서도 뚜렷한 땀분비감소 가 확인되었다; 4 명은 모든 부위에서 땀분비 감소를 보였 으며, 2 명은 발을 제외한 부분에서 땀 분비 감소를 보였다 (Fig. 1). 자율신경검사에서 뚜렷한 자율신경계 이상 소견 은 없었으나, 3명(50\%)의 환자에서 심호흡시 심박동변이 의 감소를 보였으며, 발살바 비는 정상이었다. 땀이 나지 않는 부위(대부분은 등, 가슴, 팔, 또는 다리)에서 시행한 피부조직검사에서 에크린 땀샘의 구조나 수에 변화는 없으 면서 땀샘주위 혹은 혈관주위로 경한 림프구 침윤소견이 관찰되었다( $83 \%, N=5 / 6)$.

여섯 명의 모든 환자에서 약물치료를 시행하였다. $1 \mathrm{~g}$ 의 메틸프레드니솔론을 5일간 투여하였고, 경구 프레드니솔 론은 $60 \mathrm{mg}$ 부터 시작하여 점차 용량을 줄였다. 평균 초기

Table 1. Clinical Features and Treatment Response of Patients with Acquired Idiopathic Generalized Anhidrosis

\begin{tabular}{|c|c|c|c|c|c|c|c|c|c|c|c|c|}
\hline $\begin{array}{c}\text { Case } \\
\mathrm{N} .\end{array}$ & Sex & $\begin{array}{l}\text { Age at } \\
\text { onset } \\
\text { (year) }\end{array}$ & $\begin{array}{l}\text { Disease } \\
\text { duration } \\
\text { (day) }\end{array}$ & $\begin{array}{l}\text { Follow-up } \\
\text { duration } \\
\text { (month) }\end{array}$ & $\begin{array}{c}\text { Cholinergic } \\
\text { urticaria }\end{array}$ & $\begin{array}{l}\text { Treatment } \\
\text { duration* } \\
\text { (day) }\end{array}$ & $\begin{array}{l}\text { Steroid } \\
\text { response }\end{array}$ & Recur & $\begin{array}{l}\text { Time to } \\
\text { recur after } \\
\text { Tx (day) }\end{array}$ & $\begin{array}{c}\text { Sweating area } \\
\text { on TST }\end{array}$ & $\begin{array}{c}\text { Decreased } \\
\text { sweating region } \\
\text { on QSART }\end{array}$ & $\begin{array}{l}\text { Skin } \\
\text { biopsy }\end{array}$ \\
\hline 1 & $M$ & 38 & 45 & 14 & + & 16 & Good & + & 41 & Face, axilla & All regions & Abnormal $^{\dagger}$ \\
\hline 2 & $M$ & 29 & 196 & 7 & + & 66 & Good & + & 28 & none & All regions & Normal \\
\hline 3 & M & 37 & 30 & 14 & - & 104 & Good & + & 28 & Axilla, neck & All regions & Abnormal $^{\dagger}$ \\
\hline 4 & M & 27 & 58 & 5 & + & 158 & Poor & - & $\mathrm{N} / \mathrm{A}$ & $\begin{array}{l}\text { Face, axilla, } \\
\text { palms, soles }\end{array}$ & All regions & Abnormal $^{\dagger}$ \\
\hline 5 & M & 42 & 22 & 4 & - & 106 & Good & - & $\mathrm{N} / \mathrm{A}$ & $\begin{array}{l}\text { Face, axilla, } \\
\text { elbow, wrist }\end{array}$ & $\begin{array}{l}\text { Forearm, proximal } \\
\text { leg, distal leg }\end{array}$ & Abnormal $^{\dagger}$ \\
\hline 6 & M & 16 & 564 & 4 & + & 97 & Good & - & $\mathrm{N} / \mathrm{A}$ & axilla & $\begin{array}{l}\text { Forearm, proximal } \\
\text { leg, distal leg }\end{array}$ & Abnormal $^{\dagger}$ \\
\hline
\end{tabular}

N.: number, TST: thermoregulatory sweat test, QSART: quantitative sudomotor axon reflex test, N/A: non-applicable

*Treatments include methylprednisolone $1 \mathrm{~g}$ for 5 days and then oral prednisolone tapering starting from $60 \mathrm{mg}$

${ }^{\dagger}$ Presence of perivascular and/or periappendageal lymphocytic infiltration 
A
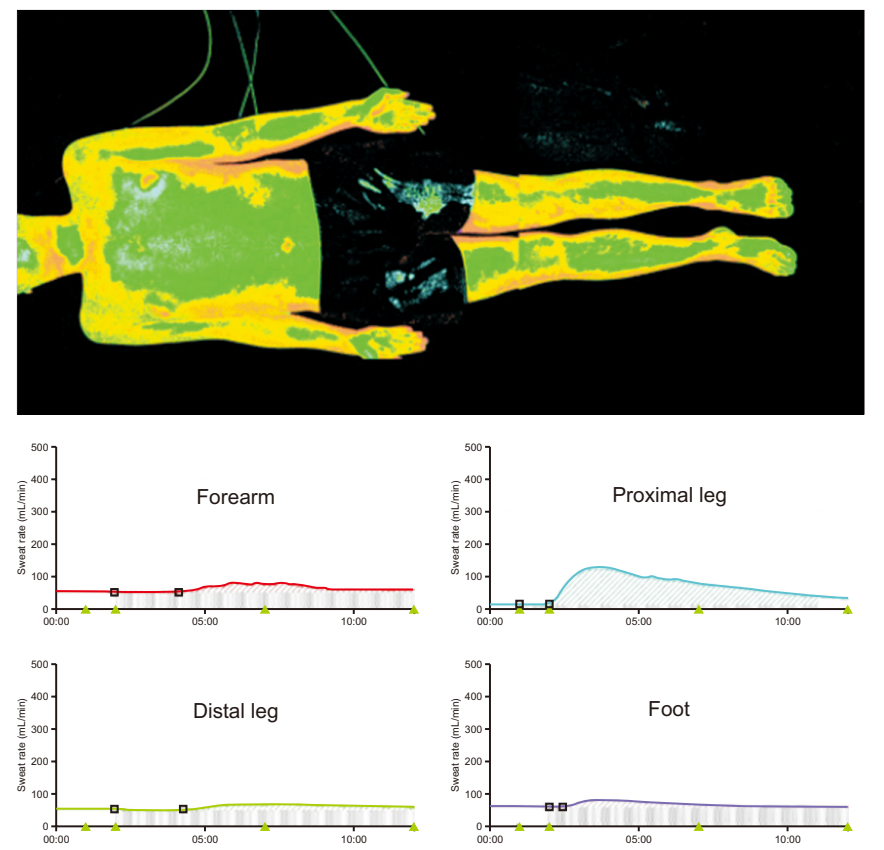

B
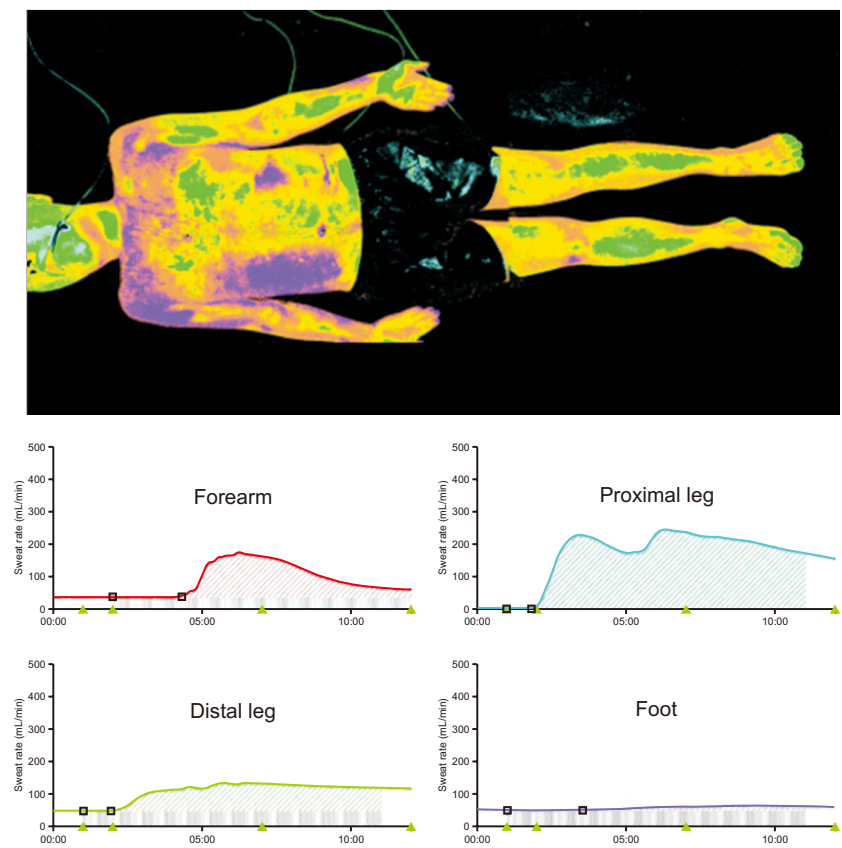

Fig. 1. The results of thermoregulatory sweat test (TST: upper part) and quantitative sudomotor axon reflex test (QSART: lower part) in a patient (case number 2) with acquired idiopathic generalized anhidrosis. Initially: sweating was not noticeable in the whole body; however, after treatment: nearly normal sweating was identified except for the foot (abnormal QSART only on the foot). (A) before and (B) after steroid treatment.

치료 기간은 91일(범위, 16 158일)이었다. 다섯 명은 스테 로이드에 대한 반응이 좋아 일상생활에 불편함이 없을 정 도로 호전되어, 경구 스테로이드를 2주 3개월 동안 복용 하고 중단하였다. 하지만 이중 3명(60\%)에서 증상이 재발 하였으며, 치료 중단 후 재발까지의 기간은 평균 32일(표준 편차 7.5)이었다. 이들에서 다시 스테로이드 치료를 시행하 였으며, 처음보다 증상 호전이 더디어 4 8개월에 걸쳐 서 서히 감량하여 중단하였고, 이후 뚜렷한 재발은 보이지 않 았다.

재발을 보인 자들은 그렇지 않은 자들과 비교하여 온도 조절 발한 검사에서 관찰되는 땀분비 감소 정도 및 범위에 서는 뚜렷한 차이를 보이지 않았으나, 정량적발한축삭반사 검사에서 더 넓은 범위에서 이상 소견을 보였다(재발군, 모 든 부위 땀분비 감소 versus 비재발군, 발에서는 정상범주 의 땀분비 발생). 증상이 재발한 3 명 중 2 명에서 심호흡시 심박동수 변이 감소가 관찰되었고, 재발하지 않은 환자에 서는 이러한 소견이 관찰되지 않았다(Fisher's exact test; $\mathrm{p}=0.088$ ). 하지만 발살바 비는 모든 환자에서 정상 수준 이었다. 이외, 발생연령, 병의 이환기간, 콜린성 두드러기 의 유무 및 피부조직검사 소견에서 유의미한 차이를 보이 지 않았다. 스테로이드에 대한 반응이 좋지 않았던 한 명에
대해서는 프레드니솔론을 $60 \mathrm{mg}$ 부터 5 10 mg/달씩 서서 히 감량하였으나, $25 \mathrm{mg}$ 복용 중 뚜렷한 호전이 없어 환자 는 자의 복용 중단하였고 추적관찰 소실되었다. 이 환자에 서는 다른 이들과 달리 항 SSB 항체 양성이었으나, FANA 및 항 SSA 항체는 음성이었으며 쇼그렌증후군 및 다른 질 환을 의심할 만한 임상 소견은 없었다.

\section{고 찰}

후천특발전신성 무한증은 땀분비 기능이상이 발생한 부위 에 따라 3 가지로 분류된다. 첫째는 다른 신경병은 없으면서 땀분비 기능에만 이상이 있는 땀샘자극신경병(sudomotor neuropathy), 둘째는 땀분비신경에서 분비된 아세틸콜린에 대하여 땀샘의 콜린수용기 반응이 감소된 상황으로 특발성 순수 땀샘자극 부전(idiopathic pure sudomotor failure), 그리고 셋째는 땀샘부전(sweat gland failure)으로 땀샘에 변형이 일어나 땀분비가 되지 않는 상황이다. ${ }^{2}$ 이 중에서 특 발성 순수 땀샘자극 부전이 가장 흔한 형태로, 젊은 남자에 서 흔하며 임상적으로 더위 불내성, 피부 통증, 이상 감각 및 콜린성 두드러기를 흔하게 호소한다. ${ }^{3}$ 다른 형태의 후천특 발전신무한증에 비하여 비교적 잘 알려져 있으며, 동질의 병 
태생리를 가지는 것으로 생각된다. 본 연구에 포함된 환자들 은 모두 젊은 남성으로, 반수에서 콜린성 두드러기를 보였 으며 자율신경검사에서 뚜렷한 이상 소견이 없고, 피부조직 검사에서 땀샘의 변형이나 감소 없이 땀샘주위 림프구 침윤 소견이 관찰되는 것으로 보아, 특발성 순수 땀샘자극 부전에 해당된다고 볼 수 있다.

현재까지 후천특발전신무한증의 치료효과를 확인하기 위 한 무작위배정 대조군 임상시험은 없으나, 여러 증례보고들 에서 전신 코티코스테로이드가 추천된다. ${ }^{2}$ 증상의 빠른 호전 을 위하여 고용량의 코티코스테로이드 펄스 치료가 좀 더 효 과적으로 사용되기도 한다. 본원의 환자들도 모두 고용량 스 테로이드 치료를 받았으며, 스테로이드에 대한 치료반응이 적었던 한 명을 제외하고 모두 펄스 치료 중 증상의 호전을 보이기 시작했다. 하지만, 코티코스테로이드 펄스 치료를 몇 회 시행하여야 하는지, 치료 후 경구 스테로이드 복용이 필 요한 것인지에 대하여는 일치된 의견이 없다. 이전 일본 연 구에서 500 1,000 mg의 메틸프레드니솔론을 1 3일동안 투여한 경우, 경구 스테로이드 추가 치료 없이도 증상의 뚜 렷한 호전이 있었다. ${ }^{1,4}$ 또한 한 연구에서는 스테로이드 등의 치료를 받지 않은 평균 8.5년의 이환기간(범위, 1 년 18.2 년)을 가지는 환자들의 $40 \%(N=4 / 10)$ 에서 자연관해를 보 이기도 했다. ${ }^{5}$ 하지만, 재발이 드물지 않음이 보고되면서 수 주에서 수개월의 스테로이드 치료를 권하기도 한다.

본 연구에 포함된 환자들 중 많은 수에서 치료 후에도 잦 은 재발을 보였다 $(60 \%$, 치료에 반응을 보였던 5명 중 3 명). 이전 사례군 연구에서도 35.7 37.5\%의 재발율을 보 고하였으나, 이보다 좀 더 높은 수치이다. ${ }^{1,4}$ 아직 재발의 위험인자에 대하여는 알려진 바가 없다. 14 명의 후천특발 전신무한증 환자들을 대상으로 한 연구에서는 재발하는 군 이 그렇지 않은 군에 비하여 나이가 더 어리고, 콜린성 두 드러기의 합병빈도가 높고, 피부조직검사에서 땀샘주위 림 프구 침윤을 보이는 경우가 더 많았으며, 증상 발생부터 치 료시작까지의 기간이 더 길었지만, 통계적 유의성은 없었 다. ${ }^{4}$ 본원에서 재발한 환자들을 보았을 때, 그렇지 않은 군 과 비교하여 뚜렷이 구별되는 특징은 찾기 어려웠다. 다 만, 정량적발한축삭반사검사에서 전신의 땀분비 감소를 보 이는 경우 재발의 빈도가 높았으며, 심호흡시 심박동수 변 화 감소가 재발을 보이는 환자에서 관찰되었다 $66 \%, N=$ 2/3). 이와 유사한 보고는 이전에 없었다. 후천특발전신무 한증은 다른 신경계 이상은 동반하지 않는 것으로 정의되 어, 이들의 진단이 맞는지 의문이 있을 수 있다. 하지만, 이
외 임상양상이나 검사 소견, 치료에 대한 반응이 진단이 합 당하여, 경한 심장미주신경 기능 저하가 동반된 형태가 존 재할 가능성을 시사한다. 땀분비 감소로 인한 중심부 체온 증가가 이차적인 심장미주신경 기능의 일시적 저하를 일으 켰을 수 있겠으나, 검사 시 체온은 정상 수준 $\left(37.2^{\circ} \mathrm{C}\right.$ 이하) 이어서 가능성은 낮은 편이다. ${ }^{6}$ 심호흡시 심박동수 변이는 추적 검사가 되지 않아 경한 심장미주신경 기능저하가 일 시적인 것이었는지는 알 수 없다. 재발 후 환자들은 처음보 다 땀분비 감소 증상의 중증도는 낮았으나 치료 반응속도 가 낮아 더 오랜 기간 스테로이드를 유지하게 되었다. 이전 증례연구에서 면역글로불린 주사치료 $(0.4 \mathrm{mg} / \mathrm{kg}, 5$ 일)를 통해 재발하는 후천특발전신무한증을 효과적으로 치료했 다는 보고도 있다. ${ }^{7}$ 보고된 환자들이 원인이 명확하지 않은 간기능이상을 동반했고, 치료와 함께 간기능이 호전되는 것으로 보아 동일한 면역학적 기전이 있었을 가능성을 시 사하였다. ${ }^{7}$ 초기의 불충분한 치료가 재발 및 감소된 치료효 과를 초래한 것이라면, 재발할 만한 요인을 발견하여 개별 화된 치료 계획을 세우는 것이 필요하다.

일부 환자에서는 스테로이드에 대한 치료반응이 없을 수 도 있다. 콜린성 두드러기가 있으면서 어린 나이에서 발병 한 경우 스테로이드에 잘 반응하며, ${ }^{4}$ 치료를 늦게 시작하거 나 조직검사 상 땀샘 실질의 변형이 많이 일어난 경우 스테 로이드 효과가 낮을 수 있다는 보고가 있다. ${ }^{2}$ 하지만, 아직 이에 대한 충분한 근거는 없으며, 추후 많은 증례들에서 확 인되어야 한다. 본원 환자 중 치료반응이 낮은 환자 한 명 은 치료 전 질병의 이환기간이 58일로 길지 않았으며, 콜 린성 두드러기도 있어 위의 경우들과는 맞지 않다. 다만 항 SSB 항체가 양성으로 확인되었고, 진단 당시 쇼그렌 증 후군 등 다른 면역질환을 시사하는 뚜렷한 소견은 없었으 나, 추후 진단명이 바뀔 가능성으로 경과관찰 중이다. 스테 로이드에 뚜렷한 효과가 없는 경우에는 다른 면역억제제 를 사용하기도 한다. 경구 사이클로스포린(cyclosporine) 이 스테로이드 펄스 치료에 반응하지 않는 후천특발전신 무한증에 효과가 있다는 보고가 있다. ${ }^{8.9}$ 사이클로스포린은 calcineurin의 작용을 방해함으로 칼슘신호전달을 저해 하고, 에크린 땀샘에 침윤하는 CD3, 그리고 CD4 T 세포 의 활성을 저해하기 때문으로 생각된다. ${ }^{9}$ 말초 교감신경에 서 분비되는 아세틸콜린은 calcineurin 매개 경로를 통해 작용하게 되는데, 사이클로스포린의 콜린성 두드러기 완화 기전을 일부 이해할 수 있다. ${ }^{10}$

본 연구는 후향적 연구로 포함된 환자의 수가 적으며 추 
적관찰기간이 길지 않았다는 점에서 제한점을 가진다. 그 럼에도 불구하고 반수 이상의 환자들이 스테로이드 치료 후 짧은 시간 내에 재발하였고 재발 후 치료 반응이 처음보 다 좋지 않았다는 점에서 발병기전연구 및 치료방법에 대 한 적극적인 관심이 필요함을 시사하였다. 또한 치료 전 경 한 심장미주신경 기능저하가 동반되는 것이 치료에 대한 반응을 예측할 수 있는 소견일 것인지 추가 연구가 필요하 겠다.

\section{References}

1. Nakazato Y, Tamura N, Ohkuma A, Yoshimaru K, Shimazu K: Idiopathic pure sudomotor failure: anhidrosis due to deficits in cholinergic transmission. Neurology 2004: 63: 1476-1480

2. Munetsugu T, Fujimoto T, Oshima Y, Sano K, Murota H, Satohet $\mathrm{T}$, et al: Revised guideline for the diagnosis and treatment of acquired idiopathic generalized anhidrosis in Japan. J Dermatol 2017: 44: 394-400

3. Ohshima Y, Tamada Y: Classification of systemic and localized sweating disorders. Perspiration Research Vol 2016: 51: 7-10
4. Ohshima Y, Yanagishita T, Ito K, Tamada Y, Nishimura $\mathrm{N}$, Inukai $\mathrm{Y}$, et al: Treatment of patients with acquired idiopathic generalized anhidrosis. Br J Dermatol 2013: 168: 430-432

5. Cao R, Tey HL: Prognosis of acquired idiopathic generalized anhidrosis. JDDG: Journal der Deutschen Dermatologischen Gesellschaft 2017: 15: 942-945

6. Turcani M, Ghadhanfar E: Biphasic changes in spontaneous cardiovagal baroreflex sensitivity during passive hyperthermia. Sci Rep 2019: 9: 2586

7. Masuda T, Obayashi K, Ueda M, Fujimoto A, Tasaki M, Misumi Y, et al: Therapeutic effects and prevention of recurrence of acquired idiopathic generalized anhidrosis via iv immunoglobulin treatment. J Derma 2016: 43: 336

8. Mok ZR, Tey HL: Acquired idiopathic generalized anhidriosis: Successful treatment with cyclosporine in two cases. Dermatol Ther 2018: 31: e12579

9. Yagi Y, Park K, Fujisawa A: Acquired idiopathic generalized anhidrosis successfully treated with cyclosporine A. Hifuka No Rinsho 2010: 52: 863-868

10. Fujii T, Takada-Takatori Y, Kawashima K: Regulatory mechanisms of acetylcholine synthesis and release by $\mathrm{T}$ cells. Life Sci 2012: 91: 981-985 